\title{
Association of Ddx5/p68 protein with the upstream erythroid enhancer element (EHS1) of the KIf1 gene
}

\author{
Xiaoyong Chen ${ }^{1}$, Felix Lohmann ${ }^{1}$, and James J Bieker ${ }^{1,2,3,4}$
}

${ }^{1}$ Department of Cell, Developmental, and Regenerative Biology, Mount Sinai School of Medicine, New York, NY, ${ }^{2}$ Black Familly Stem Cell Institute, ${ }^{3}$ Tisch Cancer Institute, ${ }^{4}$ Mindich Child Health and Development Institute, Mount Sinai School of Medicine, New York, NY

Author for correspondence:

James J Bieker, PhD

Mount Sinai School of Medicine

Department of Cell, Developmental, and Regenerative Biology

One Gustave L Levy PI - Box 1020

New York, NY. 10029

USA

212-241-5067

james.bieker@mssm.edu

Present addresses: Xiaoyong Chen, Department of Pediatrics, Yale University School of Medicine, New Haven, Connecticut, USA; Felix Lohmann, Novartis Institutes for BioMedical Research, Basel, Switzerland 


\section{Abstract}

EKLF/KLF1 is an essential transcription factor that plays a global role in erythroid transcriptional activation. It's own regulation is of interest, as it displays a highly restricted expression pattern, limited to erythroid cells and its progenitors. Here we use biochemical affinity purification to identify the Ddx5/p68 protein as a potential activator of KLF1 by virtue of its interaction with the erythroid-specific DNAse hypersensitive site (EHS1) upstream enhancer element. We postulate that its range of interactions with other proteins known to interact with this element render it part of the enhanseosome complex critical for optimal expression of KLF1.

\section{Introduction}

The mechanisms by which intracellular transcriptional regulators interact to direct hematopoietic stem cells towards a particular lineage and exert control in target expression remains a major question in cellular and molecular studies (Hewitt et al., 2014; Novershtern et al., 2011; Xu et al., 2012). Analysis of the erythroid lineage has led to the successful characterization of regulators that act as transcription factors and establish the proper network to generate erythroid-specific expression. However, in many cases it remains unresolved how these factors are themselves regulated

One way to address these issues is to isolate genomic clones that code for the gene-specific regulators and determine their own cis-acting regulatory elements and the trans-acting factors that bind to them. Based on this notion, we have been studying the regulation of erythroid Krüppel-like factor (EKLF;KLF1 (Miller and Bieker, 1993)), an erythroid-enriched transcription factor that is intimately involved in global regulation of downstream erythroid-specific gene expression by binding to cognate CCMCRCCCN elements (Siatecka and Bieker, 2011; Tallack and Perkins, 2010; Yien and Bieker, 2013). A number of functional properties and expression characteristics of KLF1 make it of interest to study its regulation.

First, KLF1 expression remains tissue-specific throughout early development and in the adult. Its onset is strictly limited to the mesodermal, primitive erythroid cells that populate the blood islands of the extraembryonic yolk sac at the early headfold stage (E7.5), switching by E9.5 to definitive cells within the hepatic primordia, and then to the red pulp of the adult spleen (Southwood et al., 1996). KLF1 is expressed at low levels in the MPP early in hematopoietic differentiation and it retains an expression pattern restricted to the CMP and MEP as its transcript levels increase prior to eventual segregation to erythroid progeny (Cui et al., 2009; Frontelo et al., 2007; Li et al., 2012).

Second, KLF1's activation target repertoire has expanded beyond the classical ß-globin gene to include protein-stabilizing, heme biosynthetic pathway, red cell membrane protein, cell cycle, and transcription factor genes in both primitive and definitive erythroid cells (Gnanapragasam and Bieker, 2017; Siatecka and Bieker, 2011; Tallack and Perkins, 2010; Yien and Bieker, 2013). Relatedly, links 
have been established between mutant or haploinsufficient levels of KLF1 and altered human hematology and anemia (Siatecka and Bieker, 2011; Singleton et al., 2012; Tallack and Perkins, 2013), as some genes are uniquely sensitive to haploinsufficient levels of KLF1 (Perkins et al., 2016; Waye and Eng, 2015).

We have shown that a 950 base pair region, located just upstream of the KLF1 transcription initiation site, is sufficient to generate erythroid-specific expression in transient assays (Chen et al., 1998). This region exhibits the most significant homology upon a seven species alignment of $30 \mathrm{kB}$ of surrounding genomic DNA (Lohmann and Bieker, 2008), and harbors erythroid-restricted DNAse hypersensitive sites. One of these sites (EHS1) behaves as a very strong enhancer, which in conjunction with the proximal promoter (Anderson et al., 1998, 2000; Crossley et al., 1994) accounts for KLF1's tissue-specific expression (Chen et al., 1998). The importance of this short region has been verified in vivo (Adelman et al., 2002; Xue et al., 2004; Zhou et al., 2010). We have suggested a twotiered mechanism for transcriptional regulation of KLF1, with GATA2 and SMAD5 proteins initially generating low transcript levels, followed by high quantities of KLF1 transcript after GATA1 protein is produced (Lohmann and Bieker, 2008). Coupled to our recent inclusion of the DEK protein into this complex along with erythroid histone marks (Lohmann et al., 2015), EHS1 can now be considered a well-characterized erythroid enhancer.

Our identification of DEK relied on a biochemical affinity purification to a region of EHS1 denoted as 'oligo2' region of EHS1 (Lohmann et al., 2015). In the present study, we have identified a second protein that also binds to that region.

\section{Materials and Methods}

32DEpo1 cells were grown as previously described (Chen et al., 1998).

EHS1-binding proteins were purified as previously described (Lohmann et al., 2015), focused on 'oligo2' (Chen et al., 1998). Briefly, M280 magnetic Dynabeads coupled with streptavidin (Life Technologies) were incubated with biotinylated oligo2 to create the oligo Dynabeads. The 32DEpo1 cell lysate (Chen et al., 1998) was added and incubation continued at room temperature with rotation. Using a magnetic apparatus, the beads were washed to remove most of the non-specific binding proteins before elution in high salt. Eluted protein was dialyzed and concentrated by acetone precipitation prior to SDS-PAGE electrophoresis. Proteins were visualized by staining with colloidal blue and bands of interest were excised. Mass spec analyses of the gel slices were performed by the Rockefeller University Protein and DNA Technology Center using the Sonar MS/MS search engine coupled with statistical scoring methods (Field et al., 2002).

Databases used as part of this study include transcription factor (Pilon et al., 2011; Stamatoyannopoulos et al., 2012), and erythroid expression (Kingsley et al., 2013) sources. 


\section{Results}

We had utilized a magnetic bead approach based on DNA affinity technology, coupled with mass spec analysis of the selected, associated proteins, to isolate proteins that bind the "oligo2" sequence within EHS1. This enabled identification of the "35kD" protein as DEK (Lohmann et al., 2015). We next focused our attention on the oligo2-enriched protein at $\sim 60 \mathrm{kD}$. MALDI/TOF isolation of peptides and their sequence analysis yielded a particularly significant hit with the p68/Ddx5 protein (Figure 1).

There is a considerable literature on this protein and its interactions with nucleic acids (FullerPace, 2006, 2013). Ddx5 is a generally expressed 'DEAD box' family protein that interacts with DNA via chromatin, and plays a role in a range of RNA processing complexes. Ddx5 contains an ATPdependent RNA helicase activity that is an important part of the Drosha complex (Davis et al., 2008; Fukuda et al., 2007), although evidence suggests that this activity is dispensable for its transcriptional regulatory function (Fuller-Pace, 2006, 2013). Disruption leads to mouse embryonic lethality by E11.5 (Fukuda et al., 2007). Ddx5's role at specific mammalian promoters has been primarily analyzed in conjunction with the ER $\alpha$ where it acts as a coactivator (Metivier et al., 2003), a function it also performs with p53, particularly at the p21 promoter (Bates et al., 2005; Nicol et al., 2013). Ddx5 acts as a barrier to reprogramming of somatic cells to pluripotency (Li et al., 2017), and its phosphorylation by c-Abl kinase plays a role in epithelial/mesenchymal transition (Yang et al., 2006).

$\mathrm{Ddx} 5$ is well expressed within erythroid cells at all stages of differentiation, and in progenitors (Figure 2). One interesting aspect in this case (compared to DEK) is that there is no evidence that p68/Ddx5 interacts with a specific DNA sequence.

Of relevance to KLF1 regulation, Ddx5 interacts with P300 and CBP (Rossow and Janknecht, 2003), and is part of a hematopoietic cell complex that forms with Scl/Tal1 (Schuh et al., 2005), a protein already known to interact with the KLF1 EHS1 region (Su et al., 2013; Wontakal et al., 2012). Ddx5 also interacts with Smad5 (Davis et al., 2008; Warner et al., 2004), a protein we and others have shown is critical for KLF1 induction (Lohmann and Bieker, 2008; Perna et al., 2015). As a result, it is relatively straightforward to envision this protein's role in KLF1 transcriptional activation via EHS1 (Figure 3).

\section{Discussion}

We have identified p68/Ddx5 as the other unique/novel protein that interacts with the 'oligo2' region of EHS1. Given that both DEK and Ddx5 were isolated from the same preparation, this suggests that they may in fact interact.

An interesting aspect is that Ddx5 performs much of its function via the long noncoding (Inc) RNA molecule SRA (Caretti et al., 2007; Watanabe et al., 2001), although a separate interaction with IncRNA Rmrp in T cells has also been described (Huang et al., 2015). The importance of the Ddx5/SRA 
interaction for transcriptional activation has been established during muscle differentiation (Caretti et al., 2006) and in insulator control of gene expression (Yao et al., 2010). Ddx5 interacts with myoD, and plays a necessary role in skeletal muscle differentiation, in part by complexing with and stabilizing the activating myoD/Brg1 interaction and aiding the recruitment of TBP and RNA pol II to muscle gene promoters (Caretti et al., 2006). Some splice variants of SRA code for the protein SRAP (Colley and Leedman, 2009, 2011; Lanz et al., 1999). At the present time, SRA has not been implicated in erythroid cell regulation.

Ddx5 also interacts with CTCF (Yao et al., 2010), a protein that plays a critical role in a range of functions including higher order chromatin structure and enhancer insulation (Phillips and Corces, 2009; Rao et al., 2014; Wallace and Felsenfeld, 2007). RNA pull-down of SRA recovers Ddx5 and CTCF in a complex (Wongtrakoongate et al., 2015). CTCF is already a well-known player in erythroid gene regulation, as it is required for proper looping at the ß-globin, SCL/TAL1, and myb transcription units (Hou et al., 2008; Lee et al., 2017; Splinter et al., 2006; Stadhouders et al., 2012; Zhou et al., 2013). These long-range interactions that involve CTCF (and likely cohesin (Hou et al., 2010)) can play a direct role in coupling tissue-restricted enhancement with a block in ectopic expression, such as that observed at the SCL/TAL1 locus (Patel et al., 2014).

Based on these properties, we hypothesize that Ddx5, in a complex with other proteins at EHS1 (Figure 3), plays a directive role in establishing a 3-dimensional structure at the KLF1 genomic locus via an interaction with CTCF. Perusal of genome browser data show that CTCF interacts within the KLF1 gene body (not shown), lending support to this general notion.

\section{Acknowledgements}

This work was supported by NIH grants DK48721 and DK46865. 


\section{Figure legends}

Figure 1. Analysis of affinity-purified proteins.

DNA binding proteins that interact with oligo2 were monitored by SDS/PAGE analysis of ${ }^{35} \mathrm{~S}$ methionine-labeled proteins after oligo1 or oligo2 affinity purification. Purified material derived from $\sim 5 \mathrm{X} 10 \mathrm{E} 6$ cell equivalents are shown. Arrowhead on right marks the protein unique to oligo 2 preparation that is the focus of this study, along with the mass spec data (Sonar MS/MS analysis: a:b:y ratio is of the fragmentation ions; ${ }^{\mathrm{z}} \mathrm{m} / \mathrm{z}^{\mathrm{m}-\mathrm{a}}$ is the ${ }^{\text {charge }}$ mass/charge ${ }^{\text {measured minus calculated }}$ mass; the vertical bar between amino acid pairs indicates the ion intensity within the peptide fragment (Field et al., 2002)) and peptide sequences used in its identification; lines on left indicate molecular weight as indicated $(k D)$.

Figure 2. Erythroid expression of Ddx5/p68.

Top, data from the Erythron database (Kingsley et al., 2013) shows expression levels of Ddx5/p68 during mouse primitive and definitive (fetal liver or bone marrow) differentiation. $P=$ proerythroblasts, $\mathrm{B}=$ basophilic erythroblasts, $\mathrm{O}=$ orthochromatiphilic erythroblasts, $\mathrm{R}=$ reticulocytes.

Bottom, browser data of RNA-seq expression in erythroid progenitors and erythroblast cells.

Figure 3. Sequence homology of KLF1 EHS1.

Detailed layout of conserved KIf1 cis-regulatory elements at the upstream enhancer (EHS1) (Lohmann and Bieker, 2008; Lohmann et al., 2015). Blocks of conserved sequence homology between seven mammalian species are color-coded for their transcription factor binding sites, highlighting Smad, DEK, Gata-Ebox-Gata sites; location of oligo2 used in this study (based on (Chen et al., 1998)) is as indicated.

Also drawn in are schematics of potential enhanceosome components at EHS1: Above includes the known multicomponent Gata/Tal1/Lmo2/Ldb1 multi-protein complex (based on (Deng et al., 2012; Li et al., 2013; Su et al., 2013; Ulirsch et al., 2014; Xu et al., 2012)); below brings in known Ddx5 protein interactions as discussed in the text. 


\section{References}

Adelman, C.A., Chattopadhyay, S., and Bieker, J.J. (2002). The BMP/BMPR/Smad pathway directs expression of the erythroid-specific EKLF and GATA1 transcription factors during embryoid body differentiation in serumfree media. Development 129, 539-549.

Anderson, K.P., Crable, S.C., and Lingrel, J.B. (1998). Multiple proteins binding to a GATA-E box-GATA motif regulate the erythroid Kruppel-like factor (EKLF) gene. J Biol Chem 273, 14347-14354.

Anderson, K.P., Crable, S.C., and Lingrel, J.B. (2000). The GATA-E box-GATA motif in the EKLF promoter is required for in vivo expression. Blood 95, 1652-1655.

Bates, G.J., Nicol, S.M., Wilson, B.J., Jacobs, A.M., Bourdon, J.C., Wardrop, J., Gregory, D.J., Lane, D.P., Perkins, N.D., and Fuller-Pace, F.V. (2005). The DEAD box protein p68: a novel transcriptional coactivator of the p53 tumour suppressor. EMBO J 24, 543-553.

Caretti, G., Lei, E.P., and Sartorelli, V. (2007). The DEAD-box p68/p72 proteins and the noncoding RNA steroid receptor activator SRA: eclectic regulators of disparate biological functions. Cell Cycle 6, 1172-1176.

Caretti, G., Schiltz, R.L., Dilworth, F.J., Di Padova, M., Zhao, P., Ogryzko, V., Fuller-Pace, F.V., Hoffman, E.P., Tapscott, S.J., and Sartorelli, V. (2006). The RNA helicases p68/p72 and the noncoding RNA SRA are coregulators of MyoD and skeletal muscle differentiation. Dev Cell 11, 547-560.

Chen, X., Reitman, M., and Bieker, J.J. (1998). Chromatin structure and transcriptional control elements of the erythroid Kruppel-like factor (EKLF) gene. J Biol Chem 273, 25031-25040.

Colley, S.M., and Leedman, P.J. (2009). SRA and its binding partners: an expanding role for RNA-binding coregulators in nuclear receptor-mediated gene regulation. Crit Rev Biochem Mol Biol 44, 25-33.

Colley, S.M., and Leedman, P.J. (2011). Steroid Receptor RNA Activator - A nuclear receptor coregulator with multiple partners: Insights and challenges. Biochimie 93, 1966-1972.

Crossley, M., Tsang, A.P., Bieker, J.J., and Orkin, S.H. (1994). Regulation of the erythroid Kruppel-like factor (EKLF) gene promoter by the erythroid transcription factor GATA-1. J Biol Chem 269, 15440-15444.

Cui, K., Zang, C., Roh, T.Y., Schones, D.E., Childs, R.W., Peng, W., and Zhao, K. (2009). Chromatin signatures in multipotent human hematopoietic stem cells indicate the fate of bivalent genes during differentiation. Cell Stem Cell 4, 80-93.

Davis, B.N., Hilyard, A.C., Lagna, G., and Hata, A. (2008). SMAD proteins control DROSHA-mediated microRNA maturation. Nature (London) 454, 56-61.

Deng, W., Lee, J., Wang, H., Miller, J., Reik, A., Gregory, P.D., Dean, A., and Blobel, G.A. (2012). Controlling long-range genomic interactions at a native locus by targeted tethering of a looping factor. Cell 149, 12331244.

Field, H.I., Fenyo, D., and Beavis, R.C. (2002). RADARS, a bioinformatics solution that automates proteome mass spectral analysis, optimises protein identification, and archives data in a relational database. Proteomics 2, 36-47.

Frontelo, P., Manwani, D., Galdass, M., Karsunky, H., Lohmann, F., Gallagher, P.G., and Bieker, J.J. (2007). Novel role for EKLF in megakaryocyte lineage commitment. Blood 110, 3871-3880.

Fukuda, T., Yamagata, K., Fujiyama, S., Matsumoto, T., Koshida, I., Yoshimura, K., Mihara, M., Naitou, M., Endoh, H., Nakamura, T., et al. (2007). DEAD-box RNA helicase subunits of the Drosha complex are required for processing of rRNA and a subset of microRNAs. Nat Cell Biol 9, 604-611.

Fuller-Pace, F.V. (2006). DExD/H box RNA helicases: multifunctional proteins with important roles in transcriptional regulation. Nucleic Acids Res 34, 4206-4215.

Fuller-Pace, F.V. (2013). The DEAD box proteins DDX5 (p68) and DDX17 (p72): multi-tasking transcriptional regulators. Biochim Biophys Acta 1829, 756-763.

Gnanapragasam, M.N., and Bieker, J.J. (2017). Orchestration of late events in erythropoiesis by KLF1/EKLF. Curr Opin Hematol 24, 183-190.

Hewitt, K.J., Sanalkumar, R., Johnson, K.D., Keles, S., and Bresnick, E.H. (2014). Epigenetic and genetic mechanisms in red cell biology. Curr Opin Hematol 21, 155-164.

Hou, C., Dale, R., and Dean, A. (2010). Cell type specificity of chromatin organization mediated by CTCF and cohesin. Proc Natl Acad Sci U S A 107, 3651-3656.

Hou, C., Zhao, H., Tanimoto, K., and Dean, A. (2008). CTCF-dependent enhancer-blocking by alternative chromatin loop formation. Proc Natl Acad Sci U S A 105, 20398-20403.

Huang, W., Thomas, B., Flynn, R.A., Gavzy, S.J., Wu, L., Kim, S.V., Hall, J.A., Miraldi, E.R., Ng, C.P., Rigo, F., et al. (2015). DDX5 and its associated IncRNA Rmrp modulate TH17 cell effector functions. Nature (London) $528,517-522$.

Kingsley, P.D., Greenfest-Allen, E., Frame, J.M., Bushnell, T.P., Malik, J., McGrath, K.E., Stoeckert, C.J., and Palis, J. (2013). Ontogeny of erythroid gene expression. Blood 121, e5-e13. 
Lanz, R.B., McKenna, N.J., Onate, S.A., Albrecht, U., Wong, J., Tsai, S.Y., Tsai, M.J., and O'Malley, B.W. (1999). A steroid receptor coactivator, SRA, functions as an RNA and is present in an SRC-1 complex. Cell 97, 1727.

Lee, J., Krivega, I., Dale, R.K., and Dean, A. (2017). The LDB1 Complex Co-opts CTCF for Erythroid LineageSpecific Long-Range Enhancer Interactions. Cell Rep 19, 2490-2502.

Li, B., Ding, L., Li, W., Story, M.D., and Pace, B.S. (2012). Characterization of the transcriptome profiles related to globin gene switching during in vitro erythroid maturation. BMC Genomics 13, 153.

Li, H., Lai, P., Jia, J., Song, Y., Xia, Q., Huang, K., He, N., Ping, W., Chen, J., Yang, Z., et al. (2017). RNA Helicase DDX5 Inhibits Reprogramming to Pluripotency by miRNA-Based Repression of RYBP and its PRC1Dependent and -Independent Functions. Cell Stem Cell 20, $462-477$ e466.

Li, L., Freudenberg, J., Cui, K., Dale, R., Song, S.H., Dean, A., Zhao, K., Jothi, R., and Love, P.E. (2013). Ldb1nucleated transcription complexes function as primary mediators of global erythroid gene activation. Blood 121, 4575-4585.

Lohmann, F., and Bieker, J.J. (2008). Activation of Eklf expression during hematopoiesis by Gata2 and Smad5 prior to erythroid commitment. Development 135, 2071-2082.

Lohmann, F., Dangeti, M., Soni, S., Chen, X., Planutis, A., Baron, M.H., Choi, K., and Bieker, J.J. (2015). The DEK Oncoprotein Is a Critical Component of the EKLF/KLF1 Enhancer in Erythroid Cells. Mol Cell Biol 35, 3726-3738.

Metivier, R., Penot, G., Hubner, M.R., Reid, G., Brand, H., Kos, M., and Gannon, F. (2003). Estrogen receptoralpha directs ordered, cyclical, and combinatorial recruitment of cofactors on a natural target promoter. Cell 115, 751-763.

Miller, I.J., and Bieker, J.J. (1993). A novel, erythroid cell-specific murine transcription factor that binds to the CACCC element and is related to the Krüppel family of nuclear proteins. Mol Cell Biol 13, 2776-2786.

Nicol, S.M., Bray, S.E., Black, H.D., Lorimore, S.A., Wright, E.G., Lane, D.P., Meek, D.W., Coates, P.J., and Fuller-Pace, F.V. (2013). The RNA helicase p68 (DDX5) is selectively required for the induction of p53dependent p21 expression and cell-cycle arrest after DNA damage. Oncogene 32, 3461-3469.

Novershtern, N., Subramanian, A., Lawton, L.N., Mak, R.H., Haining, W.N., McConkey, M.E., Habib, N., Yosef, N., Chang, C.Y., Shay, T., et al. (2011). Densely interconnected transcriptional circuits control cell states in human hematopoiesis. Cell 144, 296-309.

Patel, B., Kang, Y., Cui, K., Litt, M., Riberio, M.S., Deng, C., Salz, T., Casada, S., Fu, X., Qiu, Y., et al. (2014). Aberrant TAL1 activation is mediated by an interchromosomal interaction in human T-cell acute lymphoblastic leukemia. Leukemia 28, 349-361.

Perkins, A., Xu, X., Higgs, D.R., Patrinos, G.P., Arnaud, L., Bieker, J.J., and Philipsen, S. (2016). Kruppeling erythropoiesis: an unexpected broad spectrum of human red blood cell disorders due to KLF1 variants. Blood 127, 1856-1862.

Perna, F., Vu, L.P., Themeli, M., Kriks, S., Hoya-Arias, R., Khanin, R., Hricik, T., Mansilla-Soto, J., Papapetrou, E.P., Levine, R.L., et al. (2015). The Polycomb Group Protein L3MBTL1 Represses a SMAD5-Mediated Hematopoietic Transcriptional Program in Human Pluripotent Stem Cells. Stem Cell Reports 4, 658-669.

Phillips, J.E., and Corces, V.G. (2009). CTCF: master weaver of the genome. Cell 137, 1194-1211.

Pilon, A.M., Ajay, S.S., Kumar, S.A., Steiner, L.A., Cherukuri, P.F., Wincovitch, S., Anderson, S.M., Mullikin, J.C., Gallagher, P.G., Hardison, R.C., et al. (2011). Genome-wide ChIP-Seq reveals a dramatic shift in the binding of the transcription factor erythroid Kruppel-like factor during erythrocyte differentiation. Blood 118, e139-148.

Rao, S.S., Huntley, M.H., Durand, N.C., Stamenova, E.K., Bochkov, I.D., Robinson, J.T., Sanborn, A.L., Machol, I., Omer, A.D., Lander, E.S., et al. (2014). A 3D map of the human genome at kilobase resolution reveals principles of chromatin looping. Cell 159, 1665-1680.

Rossow, K.L., and Janknecht, R. (2003). Synergism between p68 RNA helicase and the transcriptional coactivators CBP and p300. Oncogene 22, 151-156.

Schuh, A.H., Tipping, A.J., Clark, A.J., Hamlett, I., Guyot, B., Iborra, F.J., Rodriguez, P., Strouboulis, J., Enver, T., Vyas, P., et al. (2005). ETO-2 associates with SCL in erythroid cells and megakaryocytes and provides repressor functions in erythropoiesis. Mol Cell Biol 25, 10235-10250.

Siatecka, M., and Bieker, J.J. (2011). The multifunctional role of EKLF/KLF1 during erythropoiesis. Blood 118, 2044-2054.

Singleton, B.K., Frayne, J., and Anstee, D.J. (2012). Blood group phenotypes resulting from mutations in erythroid transcription factors. Curr Opin Hematol 19, 486-493.

Southwood, C.M., Downs, K.M., and Bieker, J.J. (1996). Erythroid Kruppel-like Factor (EKLF) exhibits an early and sequentially localized pattern of expression during mammalian erythroid ontogeny. Devel Dyn 206, 248259.

Splinter, E., Heath, H., Kooren, J., Palstra, R.J., Klous, P., Grosveld, F., Galjart, N., and de Laat, W. (2006). CTCF mediates long-range chromatin looping and local histone modification in the beta-globin locus. Genes Dev 20, 2349-2354. 
Stadhouders, R., Thongjuea, S., Andrieu-Soler, C., Palstra, R.J., Bryne, J.C., van den Heuvel, A., Stevens, M., de Boer, E., Kockx, C., van der Sloot, A., et al. (2012). Dynamic long-range chromatin interactions control Myb proto-oncogene transcription during erythroid development. EMBO J 31, 986-999.

Stamatoyannopoulos, J.A., Snyder, M., Hardison, R., Ren, B., Gingeras, T., Gilbert, D.M., Groudine, M., Bender, M., Kaul, R., Canfield, T., et al. (2012). An encyclopedia of mouse DNA elements (Mouse ENCODE). Genome Biol 13, 418.

Su, M.Y., Steiner, L.A., Bogardus, H., Mishra, T., Schulz, V.P., Hardison, R.C., and Gallagher, P.G. (2013). Identification of biologically relevant enhancers in human erythroid cells. J Biol Chem 288, 8433-8444.

Tallack, M.R., and Perkins, A.C. (2010). KLF1 directly coordinates almost all aspects of terminal erythroid differentiation. IUBMB Life 62, 886-890.

Tallack, M.R., and Perkins, A.C. (2013). Three fingers on the switch: Kruppel-like factor 1 regulation of gammaglobin to beta-globin gene switching. Curr Opin Hematol 20,193-200.

Ulirsch, J.C., Lacy, J.N., An, X., Mohandas, N., Mikkelsen, T.S., and Sankaran, V.G. (2014). Altered chromatin occupancy of master regulators underlies evolutionary divergence in the transcriptional landscape of erythroid differentiation. PLoS Genet 10, e1004890.

Wallace, J.A., and Felsenfeld, G. (2007). We gather together: insulators and genome organization. Curr Opin Genet Dev 17, 400-407.

Warner, D.R., Bhattacherjee, V., Yin, X., Singh, S., Mukhopadhyay, P., Pisano, M.M., and Greene, R.M. (2004). Functional interaction between Smad, CREB binding protein, and p68 RNA helicase. Biochem Biophys Res Commun 324, 70-76.

Watanabe, M., Yanagisawa, J., Kitagawa, H., Takeyama, K., Ogawa, S., Arao, Y., Suzawa, M., Kobayashi, Y., Yano, T., Yoshikawa, H., et al. (2001). A subfamily of RNA-binding DEAD-box proteins acts as an estrogen receptor alpha coactivator through the $\mathrm{N}$-terminal activation domain (AF-1) with an RNA coactivator, SRA. EMBO J 20, 1341-1352.

Waye, J.S., and Eng, B. (2015). Kruppel-like factor 1: hematologic phenotypes associated with KLF1 gene mutations. Int J Lab Hematol 37 Suppl 1, 78-84.

Wongtrakoongate, P., Riddick, G., Fucharoen, S., and Felsenfeld, G. (2015). Association of the Long Non-coding RNA Steroid Receptor RNA Activator (SRA) with TrxG and PRC2 Complexes. PLoS Genet 11, e1005615.

Wontakal, S.N., Guo, X., Smith, C., MacCarthy, T., Bresnick, E.H., Bergman, A., Snyder, M.P., Weissman, S.M., Zheng, D., and Skoultchi, A.I. (2012). A core erythroid transcriptional network is repressed by a master regulator of myelo-lymphoid differentiation. Proc Natl Acad Sci U S A 109, 3832-3837.

Xu, J., Shao, Z., Glass, K., Bauer, D.E., Pinello, L., Van Handel, B., Hou, S., Stamatoyannopoulos, J.A., Mikkola, H.K., Yuan, G.C., et al. (2012). Combinatorial assembly of developmental stage-specific enhancers controls gene expression programs during human erythropoiesis. Dev Cell 23, 796-811.

Xue, L., Chen, X., Chang, Y., and Bieker, J.J. (2004). Regulatory elements of the EKLF gene that direct erythroid cell-specific expression during mammalian development. Blood 103, 4078-4083.

Yang, L., Lin, C., and Liu, Z.R. (2006). P68 RNA helicase mediates PDGF-induced epithelial mesenchymal transition by displacing Axin from beta-catenin. Cell 127, 139-155.

Yao, H., Brick, K., Evrard, Y., Xiao, T., Camerini-Otero, R.D., and Felsenfeld, G. (2010). Mediation of CTCF transcriptional insulation by DEAD-box RNA-binding protein p68 and steroid receptor RNA activator SRA. Genes Dev 24, 2543-2555.

Yien, Y.Y., and Bieker, J.J. (2013). EKLF/KLF1, a tissue-restricted integrator of transcriptional control, chromatin remodeling, and lineage determination. Mol Cell Biol 33, 4-13.

Zhou, D., Liu, K., Sun, C.W., Pawlik, K.M., and Townes, T.M. (2010). KLF1 regulates BCL11A expression and gamma- to beta-globin gene switching. Nat Genet 42, 742-744.

Zhou, Y., Kurukuti, S., Saffrey, P., Vukovic, M., Michie, A.M., Strogantsev, R., West, A.G., and Vetrie, D. (2013). Chromatin looping defines expression of TAL1, its flanking genes, and regulation in T-ALL. Blood 122, 41994209. 
bioRxiv preprint doi: https://doi.org/10.1101/743435; this version posted August 22, 2019. The copyright holder for this preprint (which was not certified by peer review) is the author/funder, who has granted bioRxiv a license to display the preprint in perpetuity. It is made available under aCC-BY-NC-ND 4.0 International license.

\section{Figure 1}

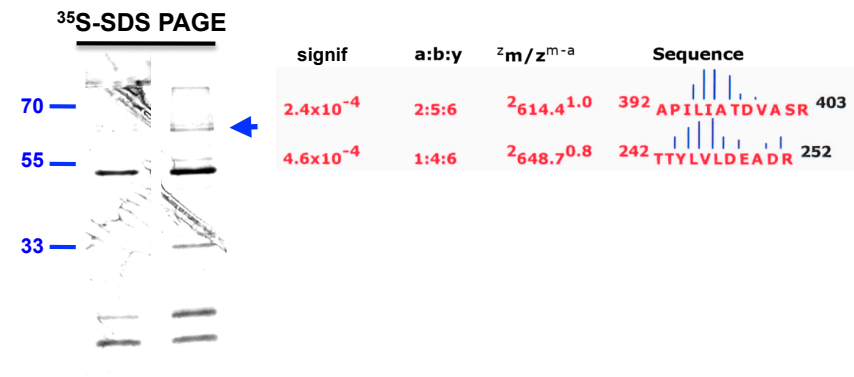

14 -

\section{2}

affinity oligo

Figure 1. Analysis of affinity-purified proteins.

DNA binding proteins that interact with oligo2 were monitored by SDS/PAGE analysis of ${ }^{35} \mathrm{~S}$ methionine-labeled proteins after oligo1 or oligo2 affinity purification. Purified material derived from 5X10E6 cell equivalents are shown. Arrowhead on right marks the protein unique to oligo 2 preparation that is the focus of this study, along with the mass spec data (Sonar MS/MS analysis: a:b:y ratio is of the fragmentation ions; $\mathrm{zm} / \mathrm{z}^{\mathrm{m}-\mathrm{a}}$ is the chargemass/charge measured minus calculated mass; the vertical bar between amino acid pairs indicates the ion intensity within the peptide fragment (Field et al., 2002)) and peptide sequences used in its identification; lines on left indicate molecular weight as indicated $(k D)$. 
bioRxiv preprint doi: https://doi.org/10.1101/743435; this version posted August 22, 2019. The copyright holder for this preprint (which was not certified by peer review) is the author/funder, who has granted bioRxiv a license to display the preprint in perpetuity. It is made available under aCC-BY-NC-ND 4.0 International license.

Figure 2

Ddx5/p68
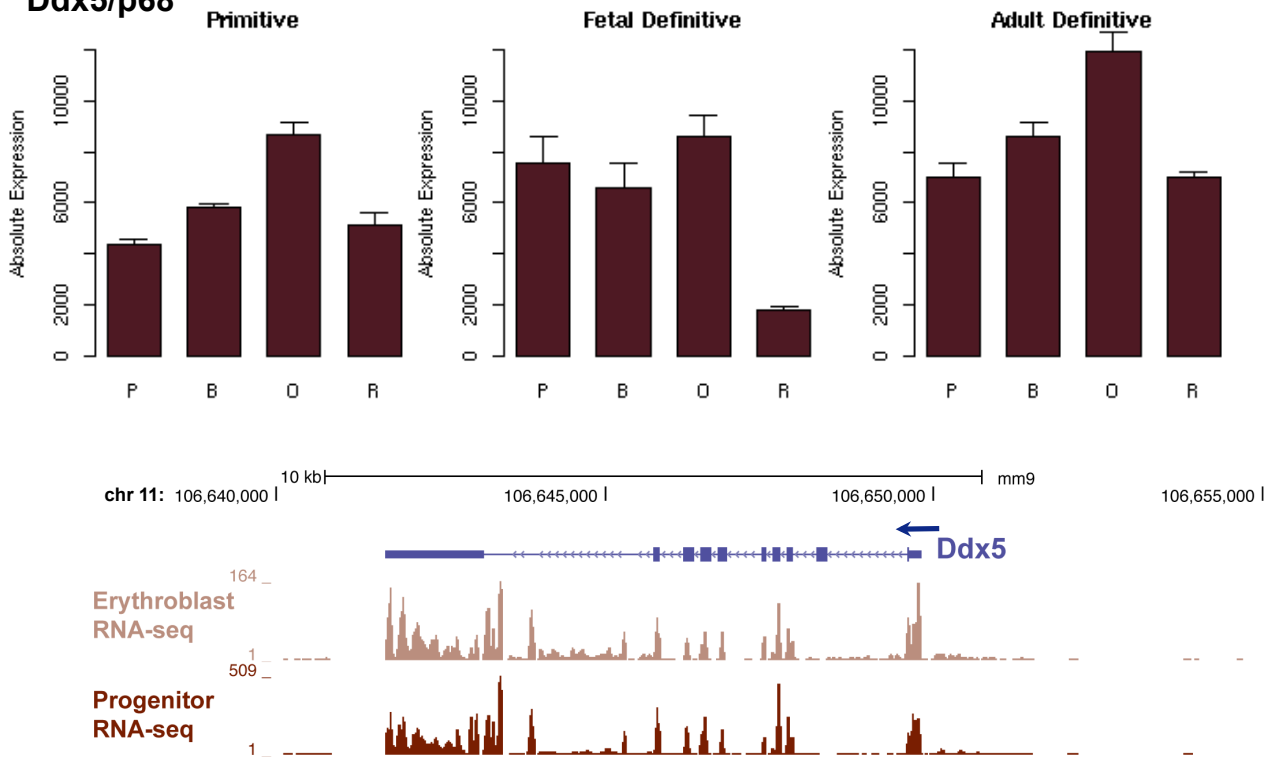

Figure 2. Erythroid expression of Ddx5/p68

Top, data from the Erythron database (Kingsley et al., 2013) shows expression levels of Ddx5/p68 during mouse primitive and definitive (fetal liver or bone marrow) differentiation. $\mathrm{P}=$ proerythroblasts, $\mathrm{B}=$ basophilic erythroblasts, $\mathrm{O}=\mathrm{orthochromatiphilic}$ erythroblasts, $\mathrm{R}=$ reticulocytes.

Bottom, browser data of RNA-seq expression in erythroid progenitors and erythroblast cells. 
bioRxiv preprint doi: https://doi.org/10.1101/743435; this version posted August 22, 2019. The copyright holder for this preprint (which was not certified by peer review) is the author/funder, who has granted bioRxiv a license to display the preprint in perpetuity. It is made available under aCC-BY-NC-ND 4.0 International license.

\section{Figure 3}

\section{EHS1=erythroid hypersensitive site 1}

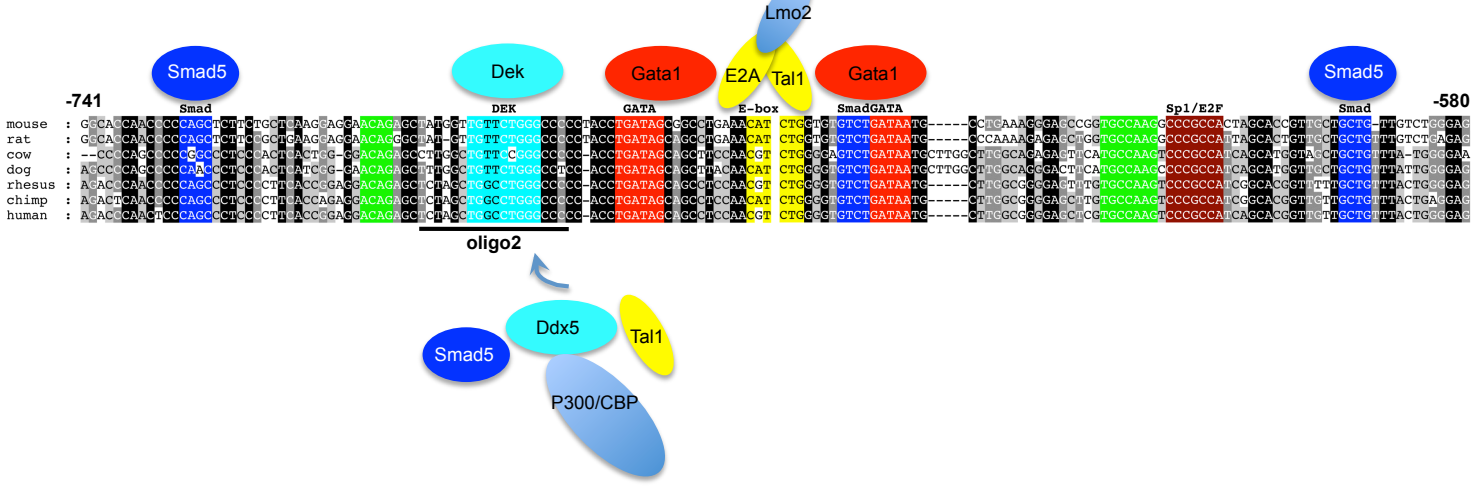

Figure 3. Sequence homology of KLF1 EHS1.

Detailed layout of conserved Klf1 cis-regulatory elements at the upstream enhancer (EHS1) (Lohmann and Bieker, 2008; Lohmann et al., 2015). Blocks of conserved sequence homology between seven mammalian species are color-coded for their transcription factor binding sites, highlighting Smad, DEK, Gata-Ebox-Gata sites; location of oligo2 used in this study (based on (Chen et al., 1998)) is as indicated.

Also drawn in are schematics of potential enhanceosome components at EHS1: Above includes the known multicomponent Gata/Tal1/Lmo2/Ldb1 multi-protein complex (based on (Deng et al., 2012; Li et al., 2013; Su et al., 2013; Ulirsch et al., 2014; Xu et al., 2012)); below brings in known Ddx5 protein interactions as discussed in the text. 